\title{
Oppimismahdollisuudet, osaaminen ja työhyvinvointi
}

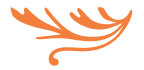 \\ Millaisia yhteyksiä löytyy henkilöstökoulutuksen, \\ oppimismahdollisuuksien, osaamisen ja työhyvinvoinnin \\ välillä? Kirjallisuuskatsaus osoittaa, että aihetta on \\ tutkittu suhteellisen vähän.
}

HENKILÖSTÖN OSAAMINEN on jo pitkään ollut yritysmaailmassa tietovaltaistuvien työorganisaatioiden strateginen kilpailutekijä. Viime aikoina on käyty keskustelua myös osaamisen johtamisen ja työhyvinvoinnin yhteydestä. Osaaminen kehittyy ja kanavoituu toiminnaksi vain hyvinvoivan henkilöstön kautta. Näin henkilöstön hyvinvoinnista huolehtiminen voidaan nähdä tärkeänä osana osaamisen johtamista. (Viitala \& Mäkipelkola 2005). Sen lisäksi, että työhyvinvointi nähdään yhtenä osaamisen kehittymisen edellytyksenä, voidaan tarkastella, miten osaaminen puolestaan vaikuttaa työhyvinvoinnin kehittymiseen. Hyvän osaamisen ja työelämän tarjoamien oppimismahdollisuuksien nähdään usein julkisessa keskustelussa itsestään selvästi edistävän työhyvinvointia. Olisi kuitenkin tärkeä tietää, miten viime aikoina osaamisen (ja sen käsiteympäristöön liittyvien tekijöiden) ja työhyvinvoinnin yhteyksiä on käsitelty ja tutkittu. Tämä on erityisen tärkeää tilanteessa, jossa työhyvinvoinnin käsitesisältöä ollaan koko ajan uudelleen määrittelemässä. Olemme siirtymässä pois stressi- ja työpahoinvointipainotteisesta työhyvinvointikäsityksestä. Tilalle on syntymässä kokonaisvaltainen ja systeeminen hyvinvointikäsitys. Uudelleenmäärittely edellyttää myös, että tärkeimpiä työhyvinvointiin vaikuttavia tekijöitä tutkitaan uudella tavalla.

Osaamisnäkökulman käsitteet - oppimis- ja kehittymismahdollisuudet ja osaaminen sekä työn hallinta - ovat laajoja ja monimerkityksisiä. Täs- 
sä tarkastelussa keskitytään työorganisaatioiden henkilöstökoulutuksen kontekstiin. Artikkelissa kysytään, miten kyseisiä käsitteitä on tieteellisissä yhteyksissä käsitelty ja määritelty ja onko työorganisaatioiden henkilöstökoulutuksen eli työpaikkakoulutuksen tarjoamien oppimismahdollisuuksien ja osaamisen sekä työhyvinvoinnin yhteyksistä olemassa tutkittua tietoa erityisesti suhteessa kokonaisvaltaiseen työhyvinvointikäsitykseen? Kuvion 1 käsitekartta auttaa tarkemmin rajaamaan artikkelin painopisteet.

Kuvion jäsennys nostaa esille useita tärkeitä kysymyksiä muun muassa (1) henkilöstökoulutuksen ja työelämän oppimismahdollisuuksien välisistä yhteyksistä (esim. millaisia oppimismahdollisuuksia ja kenelle työelämässä tarjotaan; mm. Naumanen 2002; Silvennoinen \& Nori 2012; Wiens-Tuers \& Hill 2002), (2) henkilöstökoulutuksen ja osaamisen välisistä yhteyksistä (erityisesti henkilöstökoulutuksen tuloksellisuus ja kyky tuottaa hyvää osaamista) sekä (3) henkilöstökoulutuksen yhteyksistä työhyvinvointiin. Viimemainittujen yhteyksien voidaan nähdä rakentuvan henkilöstökoulutuksen luomien hyvien oppimismahdollisuuksien tai hyvän osaamisen kautta. Yhteydet voidaan myös nähdä monimuotoisempina: voidaan ajatella, että työpaikkakoulutuksella, oppimismahdollisuuksilla ja hyvällä osaamisella saadaan aikaan myönteisiä välittäviä vaikutuksia, kuten hyvää työmotivaatiota tai työn mielekkäänä kokemista, joilla puolestaan on myönteisiä työhyvinvointivaikutuksia.

Artikkelissa keskitytään erityisesti näihin kolmannen näkökulman yhteyksiin (osoitettu paksummalla viivalla kuviossa 1), mutta muutkin käsitteisiin liittyvät kysymyksenasettelut halutaan esittää kokonaiskuvan muodostamiseksi. Tutkimuksen tavoitteena on siis tarkastella käsitteiden välisiä yhteyksiä sekä kartoittaa näihin yhteyksiin liittyviä aikaisempia tutkimuksia.
Tutkimuskysymykset asetetaan seuraavasti:

1. Miten henkilöstökoulutuksen, oppimis- ja kehittymismahdollisuuksien, osaamisen ja työhyvinvoinnin käsitteitä on tieteellisissä artikkeleissa käsitelty ja määritelty ja millaisia käsitehierarkioita niihin liittyy?

2. Miten paljon ja millaista tutkimusta käsitteiden välisistä yhteyksistä (edellä esitetyin rajauksin) on tehty ja millaisia tuloksia näissä tutkimuksissa on saatu?

Tutkimuksen alkuosan käsiteanalyysi tuottaa ne termit, joiden avulla kirjallisuuskatsauksessa voidaan kartoittaa toteutettuja tutkimuksia. Vaikka tutkimuksessa ei varsinaisia tutkimushypoteeseja asetetakaan, voidaan olettaa, että pääkäsitteistöä tarkastellen tutkimukset ovat harvalukuisia. Oletus perustuu tehtyyn työhyvinvoinnin käsitteellisen rajaukseen: työhyvinvoinnilla tarkoitetaan artikkelissa termillä 'työhyvinvointi' käsitteellistettyä ilmiötä ( 'ihmisen kokemusta omasta työperäisestä hyvinvoinnistaan'), eikä pelkästään jotain tuon kokemuksen yksittäistä tekijää, esimerkiksi työstressiä tai työuupumusta. Koska termiä 'työhyvinvointi' käytetään jatkuvasti julkisessa ja tieteellisessä keskustelussa, on tärkeää tutkia, miten tieteellisissä yhteyksissä erilaisia ilmiöitä (esim. oppimismahdollisuuksia) on tietoisesti liitetty sen käsitteelliseen yhteyteen. Näkökulma vaikuttaa hakujen rajauksiin muun muassa siten, että käsitteiden yhteyksiin liittyvää tutkimusta etsitään hakutermin työhyvinvointi (ja sen englanninkieliset vastineet) suunnasta.

\section{TARKASTELUN KÄSITEPOHJA}

Käsiteanalyyttisen tarkastelun tavoitteena on muodostaa kokonaiskuva henkilöstökoulutuksen käsiteympäristöstä ja sen liittymisestä osaamisen ja työhyvinvoinnin käsiteympäristöihin. Kuviossa 1 esitettyä viitekehystä täydennetään käsitetarkastelussa esille nostetuilla termeillä. Näin täydennetty viitekehys esitetään käsitetarkastelun jälkeen (myöhemmin kuvio 2). Samalla muodostetaan 


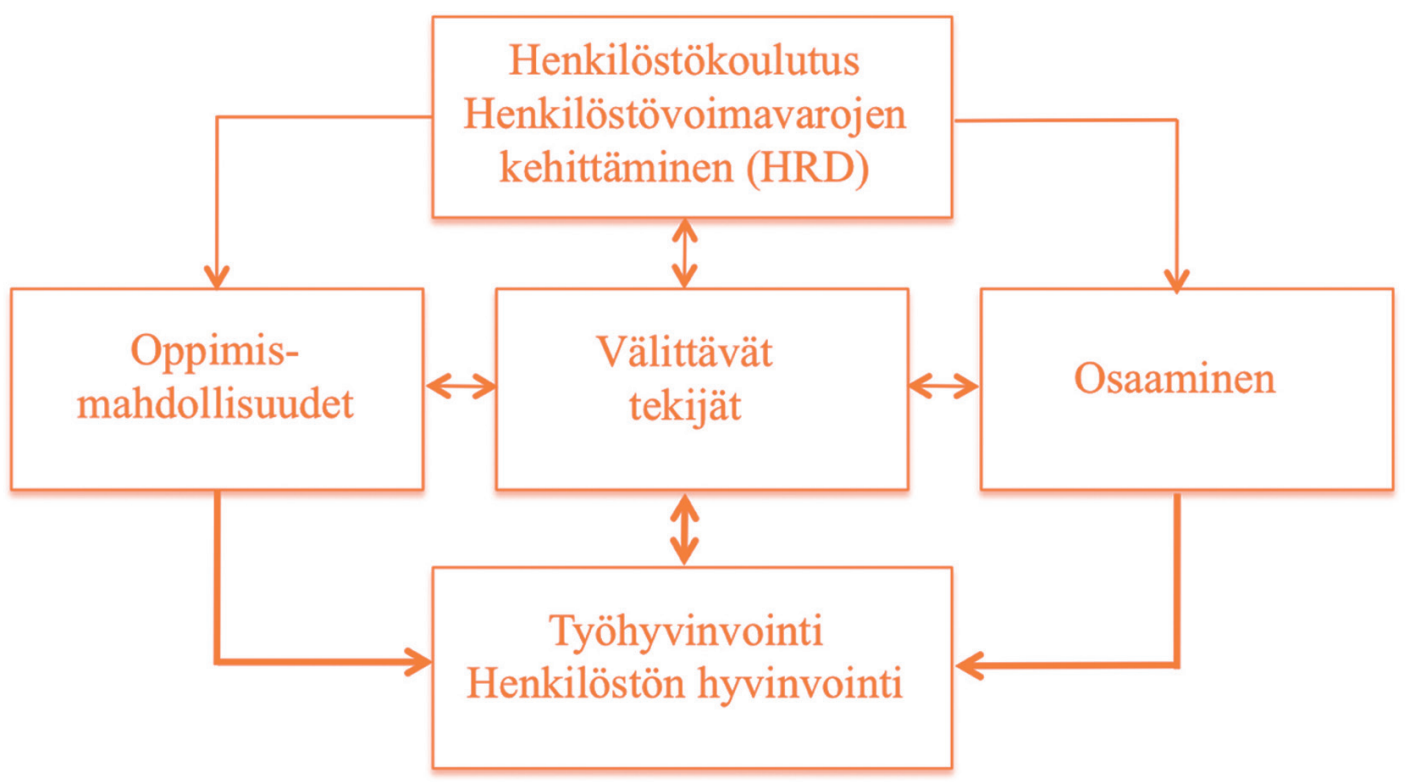

Kuvio 1. Henkilöstökoulutuksen, oppimismahdollisuuksien, osaamisen ja työhyvinvoinnin yhteydet.

edellytykset systemaattisen kirjallisuuskatsauksen hakutermien määrittelylle.

\section{Henkilöstökoulutus, oppimismahdollisuudet ja osaaminen}

Työelämä tarjoaa monenlaisia oppimisen ja kehittymisen mahdollisuuksia; nyt tarkastelussa on henkilöstökoulutuksen näkökulma. Henkilöstökoulutus on merkittävä osa ammatillista aikuiskoulutusta. Suomessa siihen osallistuu vuosittain yli miljoona palkansaajaa eli yli puolet kaikista palkansaajista (Lyly-Yrjänäinen 2014; SVT 2014). Henkilöstökoulutuksella voidaan tarkoittaa koulutusta, jonka työnantaja kustantaa joko kokonaan tai osittain. Koulutus tapahtuu pääosin työajalla, ja yleensä koulutettavalle aiheutuva ansionmenetys korvataan. (Raivola ym. 2006.) Käsite koulutus (henkilöstökoulutus) on vakiintunut muun muassa ti- lastoinnin yhteydessä käytettäväksi yleiskäsitteeksi ja sen käytöllä on pitkä aikuiskoulutukseen ja ammatilliseen aikuiskoulutukseen liittyvä perinteensä (Silvennoinen \& Laine 2014). Henkilöstökoulutuksen käsitteen rinnalla käytetään synonyymisesti käsitettä työpaikkakoulutus. Perehdyttämisessä on kyse joko uuden henkilöstön perehdyttämisestä ja opastamisesta työhön uudessa työpaikassa tai kokeneen työntekijän perehdyttämisestä uuteen työtehtävään (mm. Ketola 2010) ja siten henkilöstökoulutusta suppeammasta käsitteestä. Perehdyttämisen osana tai sen rinnalla käytetään yleisesti työnopastuksen käsitettä.

Liiketaloustieteellisessä tutkimuksessa ja kirjallisuudessa käytetään yleisesti henkilöstövoimavarojen kehittämisen (Human Resources Development, HRD) käsitettä merkitsemään koulutuksen, kehittämisen, urakehityksen ja organisaation kehittämi- 
sen keinojen integroitua käyttöä yksilön ja organisaation suorituskyvyn parantamiseksi (McLagan 1983; HRD-käsitteestä ks. mm. Harbison \& Myers 1964; Lee 1997, 2001; Hamlin 2010). Tällöin koulutus nähdään suppeammin HRD:n yhtenä osana tai menetelmänä. Myös Suomessa on omaksuttu - viimeksi koulutusvapaakeskustelun yhteydessä - näkökulma, jonka mukaan osaamista voidaan kehittää koulutuksella, ohjauksella, laajentamalla työtehtäviä sekä muilla osaamisen kehittymisen tavoilla. Muihin tapoihin sisältyvät esimerkiksi palauteprosessit, perehdytys, mentorointi, työnohjaus, coaching ja trainee-ohjelmat. (TyövirePro 2013.) Koulutus on siis nähty yhtenä osaamisen ja henkilöstön kehittämisen keinona. Tässä tutkimuksessa käytetään kuitenkin (henkilöstö)koulutuksen käsitettä laaja-alaisesti ja lähes synonyymisesti HRD:n kanssa. Henkilöstökoulutus muodostaa näin määriteltynä sen kontekstin, jossa oppimismahdollisuuksien, osaamisen ja niitä välittävien tekijöiden hyvinvointimahdollisuuksia tarkastellaan. Rajautuminen "formaaliin" henkilöstökoulutukseen sulkee luonnollisesti pois tärkeitä työelämän oppimisen muotoja, kuten työssä oppimisen.

Henkilöstökoulutuksen tarjoamia oppimismahdollisuuksia on perinteisesti tarkasteltu sosiologisesta tai yhteiskunnallisesta näkökulmasta: miten henkilöstökoulutukseen osallistutaan, miten henkilöstökoulutus jakaantuu ja millä perusteilla. Oppimismahdollisuuksia voidaan kuitenkin tarkastella myös yksilön ja työntekijän näkökulmasta. Klassisten motivaatioteorioiden ja ihmiskäsityksen mukaan jatkuva oppiminen ja kasvu ovat keskeisiä hyvän työelämän edellytyksiä. 'Henkilöstökoulutukseen liittyvät oppimismahdollisuudet' kuvaa käsitteenä niitä edellytyksiä, joita työntekijöillä on osallistua työorganisaatiossa järjestettyyn henkilöstön kehittämiseen, henkilöstökoulutukseen. Oppimismahdollisuuksilla tai laajemmin kehittymismahdollisuuksilla voidaan nähdä olevan itsenäistä merkitystä yhtenä henkilöstön hyvinvointia rakentavana tekijänä. Työnantajan tarjoamia oppimismahdollisuuksia ja toisaalta henkilöstön motivoitumista niitä hyödyntämään voidaan tarkastella yksilötekijöiden, rakenteellisten tekijöiden ja yhteiskunnallisten tekijöiden näkökulmista (Silvennoinen \& Laine 2014). Näistä yksilötekijöillä kuten iällä, sukupuolella, koulutustaustalla ja työtehtävällä (organisatorisella asemalla) voidaan ajatella olevan yhteyksiä kehittymismahdollisuuksiin ja niiden kokemiseen.

Osaamisen käsitteeseen liittyy erityisesti HRDympäristössä todella runsas joukko vaikeasti määriteltäviä ja toisistaan vaikeasti erillään pidettäviä käsitteitä. Klassinen HRD:n määritelmä (Harbison \& Myers 1964) nostaa näistä esille eräitä keskeisimpiä: "HRD is the process of increasing the knowledge, the skills, and the capacities of all the people in a society". Tiedon (knowledge), taitojen (skills) ja kyvyn tehdä jotain (capacity) rinnalla on yleisesti käytetty muun muassa kyvykkyyden (capability) ja pätevyyden (competency) käsitteitä. Kyvykkyyden käsite näytetään yleensä liitettävän organisaation ominaisuuksiin yrityksen strategisen kyvykkyyden yhteydessä (mm. Sanchez ym. 1996), kun taas pätevyys on yleensä liitetty yksilöön (mm. osaamisprofiilit, competency profiles). Osaaminen määritellään tässä yhteydessä pragmaattisesti työssä tarvittavien ominaisuuksien ja taitojen käyttämiseksi työn tavoitteiden saavuttamiseksi (Cheetham \& Chivers 2005).

Osaamisen käsitteellä viitataan perinteiseen pohjoismaiseen näkemykseen, jossa osaamiseen liitetään tiedon, taidon ja asenteiden osa-alueet. Osaamisen nähdään rakentuvan sosiaalisesti, sosiaalisena konstruktiona. Se kehittyy ja sitä kehitetään työelämässä dynaamisesti formaalien ja non-formaalien menettelyjen kautta. (mm. Paloniemi 2004.) Sen lisäksi käytetään ammatillisen osaamisen ja ammattitaidon käsitteitä, jotka liittävät osaamisen henkilöstökoulutuksen kontekstiin. Runsaan tutkimuskäytön vuoksi käytetään lisäksi competenceja competency -käsitteitä osaamisen ja pätevyyden englanninkielisenä vastineena. Työhyvinvointiyh- 
teydessä tarkasteltuna osaamisessa korostuu koettu osaaminen tai koettu työn hallinta. Kun subjektiivinen työhyvinvointi painottaa työntekijän kokemusta omasta työperäisestä hyvinvoinnistaan niin tätä kokemusta on osaltaan määrittämässä subjektiivinen kokemus omasta osaamisesta. Se ei tietenkään merkitse välttämättä samaa kuin 'objektiivinen' tai 'todellinen' osaaminen. Kun tässä kuitenkin etsitään tutkimuksia, joissa 'osaaminen' olisi liitetty työhyvinvointiin, tarvitaan käsitemäärittelyä vain niiltä osin kuin sillä on merkitystä hakutermien valintaan.

Käsitteiden hierarkkisuus hankaloittaa kirjallisuuskatsauksen tekemistä. Vaikka osaamisen ja työhyvinvoinnin yhteyttä ei olisikaan tutkittu yleiskäsitteiden tasolla, on voitu tutkia jonkin erityisen osaamisen, kuten asiakasosaamisen, tietoteknisen osaamisen tai johtamisosaamisen yhteyttä johonkin työhyvinvoinnin osa-alueeseen, esimerkiksi kuormittumiseen tai työn imuun. Hakua tehtäessä täytyy siis siirtyä yleiskäsitteistä seuraavaan alakäsiteluokkaan. Tämä taas on vaikeaa, koska esimerkiksi työhyvinvoinnin käsitteelle ei ole olemassa yhtä hyväksyttyä määritelmää, joka voitaisiin ottaa tarkastelun lähtökohdaksi.

\section{Työhyvinvointi - henkilöstön hyvinvointi}

Työhyvinvoinnin käsitteen historia sitoo sen työkykyperinteeseen, stressitutkimukseen, psykologiatieteeseen ja usein myös yksilöpatologiaan eli työuupumuksen ja muiden työperäisten ongelmien perinteeseen. Viime vuosikymmenen tutkimus on nostanut esille myös työn hyvinvointia luovia ominaisuuksia, kuten työn imun. Vallinnut yksilönäkökulma on johtanut usein siihen, että työhyvinvointiongelmien syitä on etsitty yksilöstä, ja harvemmin organisatorisista tai yhteiskunnallisista tekijöistä. Viimeaikainen tutkimus on nostanut esille työn ja työprosessien merkityksen, yksilön, organisaation ja yhteiskunnan vuorovaikutussuhteet ( $\mathrm{mm}$. työn ja muun elämän suhteen) ja organisaation sosiaalisen ympäristön ja johtamisen kysymykset.
(Hakanen 2005; Ilmarinen 2004; Kalimo \& Toppinen 1997; Laine 2013; Manka \& Siekkinen 2008; Mäkitalo 2005; Utriainen 2009.)

Työhyvinvointikäsitteen historiallinen rakentuminen näkyy hyvinvointiteemoihin liittyvien tutkimusten sisällöissä. Tutkimus ei ole ollut "työhyvinvointitutkimusta" nykyaikaisessa laaja-alaisessa merkityksessä, vaan yleensä tutkimusta jonkin yksittäisen työelämän tekijän yhteydestä johonkin työpahoinvointikysymykseen, kuten työstressiin tai työuupumukseen, esimerkkeinä Masclahin \& Leiterin (mm. 1997, 2008) ja Schaufelin ym. (mm. 1993, 1994) tutkimukset. Siinä mielessä kokonaiskäsite työhyvinvointi ei ole oikeastaan ollut tutkimuskohteena. Se aiheuttaa myös käsitteellisiä ongelmia, kun halutaan selvittää erilaisten ilmiöiden yhteyttä työhyvinvointiin. Tämän tutkimuksen lähtökohdaksi on otettu työhyvinvoinnin historiallisesti rakentunut, diskursiivinen määrittely (Laine 2013) eli kirjallisuuskatsauksen lähtökohdaksi otetaan laaja-alaisesti käsitteitä, joita voidaan ajatella liitettäväksi "nykyaikaiseen" työhyvinvointikäsitykseen sen osatekijöinä. Siinä tarkastellaan työn, työntekijän, fyysisen ja psyko-sosiaalisen työympäristön ja organisaation ulkopuolisten tekijöiden interaktiota ja vaikutusta työssä koettuun hyvinvointiin.

Viimeaikaisten määrittelyjen valtavirrassa työhyvinvoinnin käsite liitetään yksilön subjektiivisen hyvinvoinnin (Subjective Wellbeing, SWB) kokemukseen ja sitä voidaan tarkastella samalla tavoin kuin hyvinvointikäsitystä yleensäkin. Hyvinvoinnin kokemisen komponenteiksi voidaan määritellä hyvä positiivinen ja alhainen negatiivinen tunnetila sekä kognitiivinen arvio hyvästä tyytyväisyydestä elämään yleensä (Diener ym. 1999, Busseri ym. 2007; ks. myös Feldt ym. 2005; Korkalainen \& Kokko 2008). Samalla tavoin voidaan ajatella työhyvinvoinnin muodostuvan työelämän eri osa-alueiden arvioiden kokonaisuudesta ja yhteisvaikutuksista. Näin työhyvinvointi tulee kytketyksi ennemmin hyvinvointitutkimukseen kuin perinteiseen stressiteoreettiseen näkökulmaan. Tällainen työ- 
hyvinvoinnin määrittely muodostuu toisaalta subjektiivisen hyvinvointikomponentin määrittelystä ja toisaalta subjektiiviseen kokemukseen vaikuttavien tekijöiden tarkastelusta. Tämä on otettu artikkelin lähtökohdaksi siten, että etsitään erityisesti tutkimuksia, jotka tarkastelisivat oppimis- ja kehittymismahdollisuuksien ja osaamisen merkitystä subjektiivisen hyvinvointikokemuksen rakentumisessa. Koska työhyvinvoinnin käsite on viimeaikoina laajentunut ottamaan huomioon myös työn ja muun elämän vuorovaikutussuhteen, voisi olla perusteltua siirtyä puhumaan henkilöstön hyvinvoinnista. Työelämä vaikuttaa siihen oleellisesti, mutta koettu hyvinvointi on aina myös kokonaisuus, jota ei voida tarkastella ottamatta huomioon työelämän ulkopuolisten tekijöiden vaikutusta.

Kuviossa 2 systemaattisen kirjallisuuskatsauksen yhteydessä on otettu huomioon edellä esitellyt näkökulmat: subjektiivinen työhyvinvointikäsitys (yleistermi, 4YL kuviossa 2) sekä siihen yhteydessä olevat tekijät diskursiivisesti ryhmiteltyinä (diskurssit D1, D2 ja D3 kuviossa 2). Koska tässä jo lähtökohtaisesti oletettiin, että edellä esitetyllä tavalla määriteltyyn subjektiiviseen työhyvinvointikokemukseen liittyvä tutkimus on harvalukuista, haluttiin siis yleiskäsiteyhteyksien lisäksi tarkastella oppimismahdollisuuksien ja osaamisen käsitteitä myös suhteessa diskursiivisiin luokkiin jaksaminen, työn imu ja terveys ja työkyky. Luokkien kautta saamme samalla tietoa tutkimuksen kohdistumisesta työhyvinvoinnin käsitteen erilaisiin diskursseihin.

Johdannossa ja kuviossa 1 viitattiin työhyvinvointia välittäviin tekijöihin. Eräillä keskeisillä "klassisilla” käsitteillä voidaan nähdä yhteyksiä toisaalta työelämän tarjoamiin oppimis- ja kehittymismahdollisuuksiin ja osaamiseen ja toisaalta työhyvin-

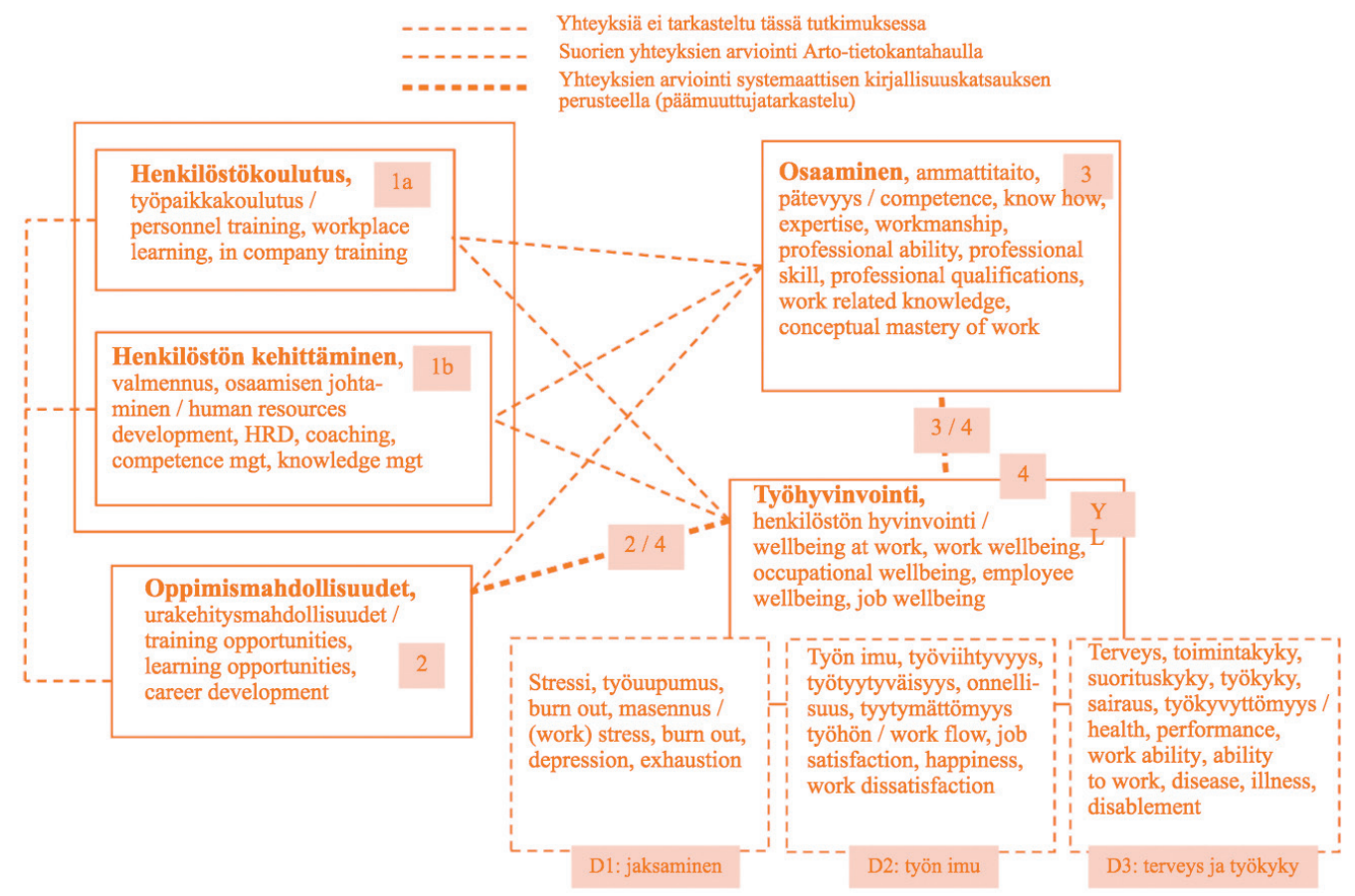

Kuvio 2. Käsitteiden väliset yhteydet ja käytetyt hakutermit (2/4 ja 3/4 -hauissa). 
vointiin. Näitä käsitteitä ovat muun muassa koherenssi (Antonovsky 1993), työn hallintamahdollisuudet (Karasek 1979; Karasek \& Theorell 1990) ja työ mielekkyyden käsite (useita näkökulmia, Suomessa mm. Alasoini 2006; Järvensivu \& Koski 2009). Voidaan kuitenkin kysyä, ovatko ne - esimerkiksi työn mielekkääksi kokeminen - erottamaton osa työhyvinvointikokemusta vai erillään tarkasteltava siihen vaikuttava tekijä. Voidaanko esimerkiksi ajatella, että hyvät oppimismahdollisuudet lisäävät työn mielekkääksi kokemista, joka puolestaan vaikuttaa työhyvinvoinnin kokemiseen. Esille nostetut tekijät ja ajatusketju ovat esimerkkejä tästä näkökulmasta, mutta empiirinen tutkimusnäyttö edellä kuvatuista yhteyksistä puuttuu. Näkökulma on kuitenkin tärkeä työhyvinvointikäsitettä edelleen operationaalistettaessa.

\section{OPPIMISMAHDOLLISUUKSIEN JA OSAAMISEN HYVINVOINTIYHTEYDET}

Fink (2005) on esittänyt mallin systemaattisen kirjallisuuskatsauksen tekemiseksi. Tätä mallia käytetään tässä soveltuvin osin. Mallin mukainen työskentely etenee siten, että tutkimuskysymysten asettamisen jälkeen valitaan tietokannat ja hakutermit, asetetaan seulat tiedonkeruun rajaamiseksi, suoritetaan katsauksen prosessointi sekä rakennetaan tutkimuksen argumentaatio ja laaditaan synteesi tuloksista (Fink 2005, 3-5; Kallio 2006, 23).

Systemaattinen kirjallisuuskatsaus tehdään kolmen päämuuttujan yhteyksiin liittyvästä tutkimuksesta. Hakua rajaavaksi seulaksi asetetaan aikarajaus 14 vuotta eli hakua tehdään vuodesta 2000 alkaen vuoteen 2013. Tätä perustellaan sillä, että keskeinen hakutermi, työhyvinvointi, on käsitteenä, siten kuin sitä edellä määriteltiin, noussut varsinaisesti esille vasta 2000-luvulta alkaen. Kotimaisessa artikkeliviitetietokannassa ARTO:ssa tehty haku termillä 'työhyvinvointi' tuotti yhteensä 755 hakutulosta (vain pieni osa vertaisarvioituja julkaisukanavia), joista kolmea lukuun ottamatta kaikki olivat aikaväliltä 2000-2014 ja tuloksista yli puolet sijoittui viimeiselle viidelle vuodelle. Sama havainto tehtiin, kun haettiin aineistoja kansainvälisistä tietokannoista. Tutkimuksen painopiste oli selvästi 2000-luvulla. Tämä kertoo työhyvinvoinnin käsitteen esille noususta; tieteellinen keskustelu sidotaan tietoisesti työhyvinvointikäsitteeseen. Kun hakuja rajataan ja työhyvinvointia tutkitaan suhteessa johonkin muuhun ilmiöön, ovat tulokset melko harvalukuisia. Siksi tarkastelua laajennettiin työhyvinvoinnin diskursiivisiin luokkiin siten kuin kuviossa 2 on esitetty. Toinen rajaus liittyy julkaisukanaviin: artikkeleja etsittiin vertaisarvioiduista tieteellisistä aikakauslehdistä. Koska hakutermien toimivuutta on tutkimusviittauksista huolimatta mahdoton täysin ennakkoon tietää, eteni tutkimus syklimäisesti eikä pelkästään lineaarisesti ja kronologisesti (vrt. Kallio 2006, 23).

Kuviossa 2 on esitetty esille nostetut käsitteet ja niiden yhteyksien tarkastelu tässä tutkimuksessa. Systemaattisen kirjallisuuskatsauksen haut (hakulauseet ja -termit) on muodostettu kuvion pohjalta. Kuvion numerointeja ja symboleja käytetään hyväksi kun viitataan yhteyksien tarkasteluun ja hakuihin.

Henkilöstökoulutuksen ja henkilöstön kehittämisen ja työhyvinvoinnin suorista yhteyksistä (1a, lb / 4YL, 4D1, 4D2, 4D3) ei löytynyt yhtään vertaisarvioitua kotimaista tutkimusta (otsikkohaku ARTO-tietokannasta) lukuisillakaan hakusanoilla (henkilöstökoulut? OR työpaikkakoulut? OR perehdyttämi? OR työnopast? OR valmen? OR työkier? OR urakehitysohjelm? OR urakehitysmall?) tarkennettuna. Oppimismahdollisuuksien ja osaamisen ja työhyvinvoinnin yhteyksiin liittyvissä hauissa $(\mathrm{H})$ etsittiin tieteellisiä artikkeleja ensin suomalaisesta ARTO-artikkelitietokannasta (H1K / $\mathrm{H} 2 \mathrm{~K}$ ). Näiden hakujen tulokset on esitetty taulukossa 1. Havaintona todetaan, että alussa esitetty olettamus päämuuttujien välisten yhteyksien kotimaisen tutkimuksen puuttumisesta piti paikkansa: yhtään vertaisarvioitua artikkelia oppimismahdollisuuksien ja työhyvinvoinnin yhteyksistä (2/4) ei 
löytynyt. Osaamisen ja työhyvinvoinnin yhteyksistä (3/4) löytyi jonkin verran artikkeleita, mutta ainoastaan kuusi vertaisarvioiduista julkaisukanavista. Missään näistä julkaisuista ei kuitenkaan käsitelty eksplisiittisesti osaamisen ja työhyvinvoinnin yhteyksiä, joten niitä ei otettu mukaan analyysiin.

Seuraavaksi tarkasteltiin ulkomaisista tietokannoista oppimis- ja kehittymismahdollisuuksien yhteyttä työhyvinvoinnin yleismäärittelyyn. Tässä edettiin siten, että ensin useista tietokannoista etsittiin vertaisarvioituja artikkeleja, joissa oli viittauksia työhyvinvointiin yleiskäsitetasolla. Nämä tietokannat valittiin kasvatustieteiden, yhteiskuntatieteiden sekä kauppa- ja taloustieteiden keskeisistä tietokannoista ja muutamista yleisistä tietokannoista (esitetty taulukossa 2). Hakulausekkeena käytettiin ("wellbeing at work" OR "work wellbeing" OR "occupational wellbeing" OR "employee wellbeing" OR "job wellbeing") -lauseketta, jolla pyrittiin kattamaan keskeisimmät englanninkieliset hakutermit. Esille nousseet artikkelit, yhteensä 508, käytiin kaikki läpi ja analysoitiin käyttämällä kuvion 2 hakutermejä sisällönanalyysin kriteereinä. Tarkastelussa yhdelläkään työhyvinvointiin liittyvällä artikkelilla ei havaittu selkeää yhteyttä työpaikkakoulutuksen tai yleensäkään koulutuksen luomiin oppimismahdollisuuksiin tai osaamiseen, joten taulukossa on esitetty pelkästään tietokannat ja työhyvinvointiosumat (taulukko 2).

Seuraavissa ulkomaisissa hauissa (H1U / H2U) laajennettiin oppimismahdollisuuksien ja osaamisen työhyvinvointiyhteyksien tarkastelua

\begin{tabular}{|c|c|}
\hline HAKUTERMIT & $\begin{array}{l}\text { TULOS } \\
\text { YHTEENSÄ/VERTAISARVIOITUJA/ } \\
\text { MUKAAN ANALYYSIIN }\end{array}$ \\
\hline $\begin{array}{l}\mathrm{H}_{1 K} \text { : oppimismahdollisuudet/ } \\
\text { työhyvinvointi } \\
2 \text { / } 4 \text { (YL) } \\
2 \text { / } 4 \text { (D1) } \\
2 \text { / } 4 \text { (D2) } \\
2 \text { / } 4 \text { (D3) }\end{array}$ & $\begin{array}{l}\mathrm{H}_{1 K}: \text { oppimismahdollisuudet/ } \\
\text { työhyvinvointi } \\
0 \\
0 \\
0 \\
0\end{array}$ \\
\hline $\begin{array}{l}\mathrm{H}_{2 \mathrm{~K}}: \text { osaaminen/ } \\
\text { työhyvinvointi } \\
3 / 4 \text { (YL) } \\
3 / 4 \text { (D1) } \\
3 \text { / } 4 \text { (D2) } \\
3 / 4 \text { (D3) }\end{array}$ & $\begin{array}{l}\mathrm{H}_{2 \mathrm{~K}}: \text { osaaminen/ } \\
\text { työhyvinvointi } \\
35 / 3 / 0 \\
3 / 0 / 0 \\
38 / 2 / 0 \\
29 / 1 / 0\end{array}$ \\
\hline Yhteensä & $105 / 6 / 0$ \\
\hline
\end{tabular}

Taulukko 1. Systemaattisen kirjallisuuskatsauksen tulokset ARTO-tietokannassa.

\begin{tabular}{|l|c|}
\hline TIETOKANTA & $\begin{array}{c}\text { HAKUTULOKSIA } \\
\text { YHTEENSÄ }\end{array}$ \\
\hline ERIC & 7 \\
\hline Education Research Complete & 11 \\
\hline Academic Search Premier (EBSCO) & 72 \\
\hline PsycArticles & 2 \\
\hline Social Sciences Citation Index (Web of Science) & 24 \\
\hline ABI/INFORM Global & 47 \\
\hline Business Source Complete (EBSCO) & 65 \\
\hline Emerald Journals (Emerald) & 34 \\
\hline Sociological Abstracts & 1 \\
\hline ScienceDirect & 190 \\
\hline SocINDEX With Full Text & 7 \\
\hline JSTOR & 2 \\
\hline PsyclNFO & 46 \\
\hline Yhteensä & 508 \\
\hline
\end{tabular}

Taulukko 2. Työhyvinvoinnin yleiskäsitteeseen liittyvät haut eri tietokannoista. 


\begin{tabular}{|l|l|}
\hline HAKUTERMIT & $\begin{array}{l}\text { TULOS } \\
\text { YHTEENSÄ/VERTAISARVIOITUJA } \\
\text { /MUKAAN ANALYYSIIN }\end{array}$ \\
\hline $\mathrm{H}_{1 \mathrm{U}}:$ & $\mathrm{H}_{1 \mathrm{U}}:$ \\
$2 / 4$ (D1) & $77 / 18 / 12$ \\
$2 / 4$ (D2) & $154 / 17 / 12$ \\
$2 / 4$ (D) & $288 / 5 / 1$ \\
Yhteensä & $519 / 40 / 25$ \\
& \\
$\mathrm{H}_{2 U}:$ & $\mathrm{H}_{2 U}:$ \\
$3 / 4$ (D1) & $609 / 11 / 5$ \\
$3 / 4$ (D2) & $252 / 19 / 11$ \\
$3 / 4$ (D3) & $507 / 4 / 2$ \\
Yhteensä & $1368 / 34 / 18$ \\
& \\
Kaikki yhteensä & $1887 / 74 / 43$ \\
\hline
\end{tabular}

Taulukko 3. Tulokset työhyvinvointidiskurssien mukaan ulkomaisessa aineistossa (Artikkelien määrä. Lyhenteistä ks. kuvio 2 ja teksti.).

jaksamisen (D1), työn imun (D2) ja terveyden ja toimintakyvyn (D3) diskursseihin. Tietokantojen määrää supistettiin suuren aineistomäärän ja hakutermien määrän vuoksi kahdeksaan oleellisimpaan. Ulkomaisissa tietokannoissa haut kohdistettiin pääasiassa abstrakteihin, mutta osassa tapauksista abstraktihaku tuotti niin suuren määrän tuloksia (useita tuhansia), että haku tehtiin otsikkohakuna. Se, että suuri osa hauissa käytetyistä sanoista oli lähinnä luonnollisen kielen sanoja eikä erikoistuneita tieteellisiä termejä, tuotti kohtuuttoman suuren määrän hakutuloksia. Esimerkiksi hakutermit 'health' ja 'performance' jouduttiin jättämään osassa hauista pois niiden tuottaman suuren epärelevantin osumamäärän vuoksi. Tärkeintä oli, että työkykyyn viittaavat termit voitiin kaikissa D3-hauissa säilyttää. Kokonaiskattavuuden uskotaan olevan näinkin toteutettuna suhteellisen hyvä. Tutkimuksen näkökulman laajuuden vuoksi hakutermit olivat tarkennettuinakin suhteellisen yleisiä, ja tästä seurasi, että hakujen "tuottoaste" oli melko heikko: yhteensä 1 887 hakutuloksesta vain 74 artikkelia (3,9\%) otettiin tarkempaan analyysiin. Vaikka työhyvinvoinnin ja osaamisen yhteyksiin liittyviä osumia (1 368) oli lähes kolminkertainen märä oppimismahdolli- suuksien ja työhyvinvoinnin yhteyksiin (519) liittyviin artikkeleihin verrattuna, löytyi tarkempaan analyysiin enemmän oppimismahdollisuuksiin liittyviä artikkeleja (40) kuin osaamiseen liittyviä (34). (Taulukko 3.)

Edellä esitetyssä analyysissä (taulukko 2) todettiin siis, että työhyvinvointiin yleiskäsitteen tasolla tehtyjä tutkimuksia ei ulkomaisistakaan artikkeleista löydetty. Diskursseihin kohdistuneissa hauissa lähempään tarkasteluun valituista 74 artikkelista suurimman ryhmän muodostivat työn imun ja työtyytyväisyyden diskurssiin (D2) liittyvät artikkelit, joita oli 36 eli $49 \%$ kaikista. Tämä kertoo tämän diskurssin esille noususta ja suosiosta viime vuosina. Jaksamisen diskurssiin liittyi 29/39\% ja terveyden ja työkyvyn diskurssiin 9/12\% artikkeleista. Viimeksi mainitun pieni osuus erityisesti hakuosumiin verrattuna johtui siitä, että artikkelit oli tehty pääasiassa lääketieteen näkökulmasta ilman relevanttia sidosta osaamiseen tai oppimismahdollisuuksiin. Siksi ei myöskään lääketieteen tietokantoja (mm. Pubmed) haluttu ottaa mukaan hakuihin.

Kaikkien 74 artikkelin abstraktit tulostettiin ja niitä tarkasteltiin sisällönanalyyttisesti suhteessa edellä määriteltyihin hakutermeihin ja -kriteereihin. Epävarmoissa tapauksissa valinta varmistettiin artikkelin koko sisältöä tarkastelemalla. Analyysin perusteella lopulliseen tarkasteluun päädyttiin ottamaan mukaan yhteensä 43 artikkelia. Näiden pohjalta laaditun yhteenvedon tulokset on esitetty

\section{taulukoissa 4 ja 5 .}

Referoitujen tutkimusten yksittäisiä tuloksia tarkasteltaessa huomataan muun muassa, että oppimismahdollisuuksilla näyttäisi olevan pääasiassa positiivisia hyvinvointivaikutuksia, mutta oppimismahdollisuuksiin liittyviin urakehitysmahdollisuuksiin näyttäisi liittyvän lisäksi stressiä luovia tekijöitä. Myös hyvällä osaamisella ja ammattitaidolla näyttäisi olevan pääasiassa myönteisiä hyvinvointivaikutuksia, mutta tässäkään tapauksessa vaikutukset eivät ole yksinkertaisia ja ammatilliseen kehittymiseen näyttäisi liittyvän myös hyvinvointia 


\begin{tabular}{|c|c|c|}
\hline TUTKITTU YHTEYS & TUTKIMUSTULOS & VIITETIEDOT \\
\hline $\begin{array}{l}\mathrm{H}_{1 \mathrm{u}} \text { : oppimis- ja } \\
\text { urakehitysmahdollsuuksien ja } \\
\text { työhyvinvoinnin yhteys } \\
\text { 2/4 D1 (Stressi, työuupumus, } \\
\text { masennus) }\end{array}$ & $\begin{array}{l}\text { (1) } \\
\text { Työpaikkakoulutus ja kehitysmahdollisuudet } \\
\text { vähentävät tai ehkäisevät työuupumusoireita } \\
\text { tai stressiä. Toisaalta urakehityksen esteet } \\
\text { aiheuttavat stressiä. } \\
\\
\text { (2) } \\
\text { Urakehitys edellyttää koulutusmahdolli- } \\
\text { suuksia ja ammatillista kehittymistä. Tämä } \\
\text { parantaa työllistymismahdollisuuksia. } \\
\text { Urakehitykseen ja työtehtävien täyttöön } \\
\text { liittyvät odotukset voivat myös aiheuttaa } \\
\text { stressiä. } \\
\text { Muut tematiikkaan liittyvät havainnot: } \\
\text { Esimiesten toteuttaman valmennuksen } \\
\text { lcoachingl merkitys stressin vähentäjänä } \\
\text { oli kyseenalainen. Urakehitysmotivaatio oli } \\
\text { yhteydessä oppimiseen ja kehittymiseen } \\
\text { liittyvään stressiin. }\end{array}$ & $\begin{array}{l}\text { (1) } \\
\text { Johnston ym. 2013, Panari ym. 2010, Van } \\
\text { Emerik 2004, Liang \& Hsieh 2005, Sethi ym. } \\
\text { 2004, Colligan \& Higgins 2008, Akkermans ym. } \\
\text { 2013, Proost ym. 2011, Van Ruysseveldt } 2011 . \\
\text { (2) } \\
\text { Bessick \& Naicker 2013, Chang \& Lu 2007, } \\
\text { Berriman } 2007 .\end{array}$ \\
\hline $\begin{array}{l}\text { 2/4 D2 (työn imu, } \\
\text { työtyytyväisyys, onnellisuus, } \\
\text { tyytymättömyys työhön) }\end{array}$ & $\begin{array}{l}\text { (1) } \\
\text { Koulutusmahdollisuudet, koulutuksen } \\
\text { sosiaalinen tuki ja koulutuksen koetut } \\
\text { hyödyt ja työssä oppiminen edistivät } \\
\text { työtyytyväisyyttä. } \\
\text { (2) } \\
\text { Organisaation tuki urakehitykselle ja } \\
\text { kehittymismahdollisuudet edistivät } \\
\text { työtyytyväisyyttä (mm. hoitohenkilöstö, } \\
\text { R\&D-henkilöstö). Henkilön ja uran } \\
\text { yhteensopivuuden ja työtyytyväisyyden suhde } \\
\text { oli käyräviivainen. Urakehitysohjelmalla } \\
\text { voitiin lisätä henkilöstön tyytyväisyyttä ja } \\
\text { ammatillista kehittymistä. } \\
\text { Muut tematiikkaan liittyvät havainnot: } \\
\text { Myös mentoroijat voivat hyötyä } \\
\text { mentoroinnista; mentorointisuhde on } \\
\text { vastavuoroinen ja lisää työtyytyväisyyttä. } \\
\text { Uramahdollisuuksia voitiin lisätä hoitotyössä } \\
\text { työkierrolla. Työkierron järjestämistä } \\
\text { haittasivat organisaation pieni koko ja } \\
\text { selkeiden uramallien puute }\end{array}$ & $\begin{array}{l}\text { (1) } \\
\text { Rowden \& Conine Jr 2005, } \\
\text { Hosie ym. 2013, Gazioglu \& Tansel 2006, Barlet } \\
\text { 2001, Akerboom \& Maes } 2006 . \\
\text { (2) } \\
\text { Kim 2009, Weng ym. 2010, Cha ym. 2009, Chen } \\
\text { ym. 2004, Chen ym. } 2003\end{array}$ \\
\hline 2/4 D3 (terveys ja työkyky) & $\begin{array}{l}\text { (1) } \\
\text { Oppimismahdollisuudet olivat yhteydessä } \\
\text { sydän- ja verisuonisairauksien ehkäisyn } \\
\text { kannalta terveelliseen käyttäytymiseen ja } \\
\text { pulssitason ja verenpaineen laskuun }\end{array}$ & $\begin{array}{l}\text { (1) } \\
\text { Rau } 2006\end{array}$ \\
\hline
\end{tabular}

Taulukko 4. Oppimismahdollisuuksien

ja työhyvinvoinnin yhteydet. 


\begin{tabular}{|c|c|c|}
\hline TUTKITTU YHTEYS & TUTKIMUSTULOS & VIITETIEDOT \\
\hline $\begin{array}{l}\mathrm{H}_{2 \mathrm{U}} \text { : osaamisen, } \\
\text { ammattitaidon } \\
\text { ja pätevyyden ja } \\
\text { työhyvinvoinnin yhteys. } \\
\text { 3/4 D1 (Stressi, } \\
\text { työuupumus, masennus) }\end{array}$ & $\begin{array}{l}\text { (1) } \\
\text { Sosiaalityöntekijät, jotka tunsivat itsensä päteviksi } \\
\text { hoitotyössään, olivat vähemmän stressaantuneita } \\
\text { ja heillä oli vähemmän työuupumusoireita. } \\
\text { Odotukset ammatillisen pätevyyden säilyttämisestä } \\
\text { aiheuttivat stressiä osalle työntekijöistä IT-alalla. } \\
\text { Oppimisprosessiin liittyvät vaikutusmahdollisuudet } \\
\text { tekivät ammattitaidon kehittämisestä } \\
\text { houkuttelevampaa ja vähensivät oppimiseen } \\
\text { liittyvää stressiä. } \\
\text { Ammatillisen pätevyyden kasvattaminen oli keino } \\
\text { masennuksesta johtuvien oireiden käsittelyyn. } \\
\\
\text { Muut tematiikkaan liittyvät havainnot: } \\
\text { Työn resurssitekijät (JDC-S -mallissa) olivat } \\
\text { yhteydessä työhön sitoutumiseen kun taas } \\
\text { vaatimustekijät työuupumukseen. Osaaminen } \\
\text { ("mastery of skills") liittyy näihin yhteyksiin. }\end{array}$ & $\begin{array}{l}\text { (1) } \\
\text { Acker \& Lawrence 2009, } \\
\text { Tsai ym. 2007, } \\
\text { Paulsson ym. 2005, } \\
\text { Pan ym. 2011, } \\
\text { Hultell \& Gustavsson } 2011 .\end{array}$ \\
\hline $\begin{array}{l}\text { 3/4 D2 (työn imu, } \\
\text { työtyytyväisyys, onnellisuus, } \\
\text { tyytymättömyys työhön) }\end{array}$ & $\begin{array}{l}\text { (1) } \\
\text { Mahdollisuudet oman korkeatasoisen } \\
\text { ammattitaidon käyttämiseen omassa työssä } \\
\text { lisäävät onnellisuutta työelämässä. Pätevyys- } \\
\text { ja osaamiskomponentti on yleensä mukana } \\
\text { onnellisuuskäsityksissä. Tyytyväisyys omaan } \\
\text { osaamiseen ja käsitys itsestä oman työn osaajana } \\
\text { ovat yhteydessä koettuun työtyytyväisyyteen. } \\
\text { Työtyytyväisyyttä voidaan parantaa lisäämällä } \\
\text { työn vaatimusten ja työntekijän pätevyyden } \\
\text { yhteensopivuutta. } \\
\text { (2) } \\
\text { Työpäivän hetkiin liittyvän onnellisuuskokemuksen } \\
\text { (momentary happiness) tutkimuksessa havaittiin, } \\
\text { että sitoutuminen pätevyyden lisäämiseen tuotti } \\
\text { affektiivisia kustannuksia. } \\
\text { Ammatillisesti pätevämmät työntekijät eivät } \\
\text { olleet sen tyytyväisempiä työhönsä kuin } \\
\text { vähemmän pätevät. Sen sijaan paremmat } \\
\text { kommunikaatiotaidot omaavat olivat tyytyväisempiä } \\
\text { kuin vähemmän taitavat. } \\
\text { Muut tematiikkaan liittyvät havainnot: } \\
\text { Kuuden kuukauden onnellisuusohjelmaan liittyi } \\
\text { mm. osanottajien ammattitaidon kehittäminen. } \\
\text { Ohjelmalla onnistuttiin parantamaan myös } \\
\text { osanottajien onnellisuutta. }\end{array}$ & $\begin{array}{l}\text { (1) } \\
\text { Martin 2011, Kehle \& Bray 2004, Graves \& } \\
\text { Luciano 2013, Bowling ym. 2010, Ryan ym. } \\
\text { 2008, Samman 2007, Ko 2012, Smith } 2005 . \\
\text { (2) } \\
\text { Howell ym. } 2011 . \\
\text { De Grip ym. } 2009 .\end{array}$ \\
\hline 3/4 D3 (terveys ja työkyky) & $\begin{array}{l}\text { (1) } \\
\text { Koettu matala ammatillinen kompetenssi } \\
\text { (OC, occupational competence) oli yhteydessä } \\
\text { koettuun negatiiviseen tunnetilaan (NES, negative } \\
\text { emotional state). } \\
\text { Muodollisesti epäpätevät hoitajat kokivat } \\
\text { suurempaa työkuormitusta, enemmän } \\
\text { unettomuutta ja enemmän stressioireita } \\
\text { kuin muodollisesti pätevät kollegansa. } \\
\text { Epäpätevyys näyttäisi olevan psykosomaattisille } \\
\text { terveysongelmille altistava tekijä. }\end{array}$ & $\begin{array}{l}\text { (1) } \\
\text { Murad ym. } 2013 . \\
\text { Engström ym. } 2011 .\end{array}$ \\
\hline
\end{tabular}

Taulukko 5. Osaamisen ja työhyvinvoinnin yhteydet. 
kuluttavia tekijöitä ja emotionaalisia kustannuksia. Toisaalta heikko ammattitaito saattaa altistaa helpommin kuormituksen kokemiselle ja olla yhteydessä stressiin ja psykosomaattisiin terveysongelmiin.

\section{YHTEENVETO}

Tutkimuksen ensimmäinen kontribuutio liittyy työhyvinvoinnin ja oppimis- ja kehittymismahdollisuuksien ja osaamisen yhteyden tarkasteluun. Kaikkien analyysien pohjalta tehtävä johtopäätös on, että työelämän koulutus- ja oppimismahdollisuuksien ja osaamisen työhyvinvointiyhteyksistä on tehty vielä suhteellisen vähän tutkimusta. Tässä viitataan siis erityisesti työhyvinvointiin yläkäsitteenä, subjektiivisen työperäisen hyvinvoinnin kokemuksena. Sikäli kuin edellä mainittuihin yhteyksiin liittyvää tutkimusta on tehty, se on yleensä liittynyt johonkin työhyvinvoinnin kapeampaan näkökulmaan tai osa-alueeseen. Tästä käsitteellisestä ”ongelmasta” johtuen tulokset oppimis- ja osaamistekijöiden ja työhyvinvoinnin yhteyksistä jäivät ohuiksi. Kun kuitenkin työhyvinvoinnin käsitteeseen liitettyä tutkimusta sinänsä (taulukko 2) oli jo jonkin verran tehty, kertoo oppimis- ja osaamisnäkökulmien puuttuminen myös siitä, että tutkimusintressiä näihin kysymyksiin liittyen ei ole ollut kovin runsaasti. Osin on varmaan kysymys vahvasta työhyvinvointitutkimuksen traditiosta: tutkimusta tuntuvat edelleen dominoivan perinteiset työn kuormitustekijät ja jaksamiskysymykset. Tosin uutena näkökulmana on voimakkaasti noussut esille työn imun ja voimavaratekijöiden tutkimus, joka saattaa pitää sisällään myös osaamis- ja kehittymisnäkökulmia, mutta niiden tarkempaan analyysiin ei tässä ollut mahdollisuutta.

Toinen tutkimuksen kontribuutio liittyy työhyvinvoinnin käsitteellistämiseen. Vaikka työhyvinvointi esiintyy käsitteenä jatkuvasti yhteiskunnallisessa keskustelussa, tämä tutkimus osoittaa esimerkkinä, miten hankalaa on tutkia jonkin yksittäisen tekijän (vaikkapa työpaikkakoulutuksen) työhyvinvointimerkitystä ennen kuin työhyvinvointi on käsitteenä operationalisoitu niin, että se voidaan yleisesti hyväksyä. Tämä näkyy muun muassa suurten kansallisten työelämätutkimusten (esim. tilastokeskuksen työolobarometrit, Työterveyslaitoksen Työ ja Terveys -tutkimus) aineistoissa, joissa työhyvinvointia ei ole käsitteenä pyritty operationaalistamaan. Hyvinvointiin, myös työperäiseen sellaiseen, liittyvää tutkimusta on tehty vuosikymmenet. On kuitenkin eri asia tutkia jonkin asian yhteyttä subjektiiviseen hyvinvointikokemukseen tai sen systeemiseen rakentumiseen kuin sen johonkin osatekijään, vaikkapa työstressin kokemiseen. Tarvitaan 'työhyvinvointi' yleiskäsite, mutta tarvittaisiin myös sen luotettava operationalisointi (summamuuttuja tai 'työhyvinvointi-indeksi' siten kuin meillä on työkykyindeksikin), jonka avulla voitaisiin seurata työelämän kehittymistä ja johon erilaisten työelämätekijöiden merkitystä voitaisiin suhteuttaa.

\section{LOPUKSI}

Artikkelin johdannossa kysyttiin ensin, miten oppimismahdollisuuksien, osaamisen ja työhyvinvoinnin käsitteitä on tieteellisissä yhteyksissä käsitelty ja määritelty. Seuraava kysymys kuului, onko työelämän tarjoamien oppimismahdollisuuksien (työpaikkakoulutuksen), osaamisen ja työhyvinvoinnin yhteyksistä olemassa tutkittua tietoa? Osaamisen käsitteelliseen ja filosofiseen tarkasteluun liittyy monimuotoinen tutkimusperinne, joka erityisesti HRD-käsiteympäristössä on todella runsas ja sisältää joukon vaikeasti määriteltäviä ja toisistaan vaikeasti erillään pidettäviä käsitteitä. Tämä yhdessä työhyvinvointikäsitteen monimuotoisuuden kanssa vaikeutti yhteyksien tarkastelua.

Laajan näkökulman ja tutkimusalueen käsitteellisen kehittymättömyyden vuoksi hakujen toteuttaminen oli haasteellista ja haut tuottivat suuren määrän tässä epärelevanttia aineistoa. Systemaattista kirjallisuuskatsausta voidaan lähes rajattomasti syventää ja tarkentaa sekä tietokantojen että hakuter- 
mien osalta. Kun tässä ei kuitenkaan etsitty mitään spesifiä tai tarkkaa yksittäistä tutkimustulosta vaan tutkimuksen painopistettä ja pälinjoja, uskotaan, että toteutettu suhteellisen väljä analyysi antoi riittävän hyvä yleiskuvan.

Lopulliseen analyysiin valikoituneiden artikkelien perusteella voidaan suhteellisen varmasti todeta, että esitetty toinen kysymys työhyvinvoinnin yhteyksistä työelämän oppimismahdollisuuksiin ja työntekijöiden osaamiseen on vielä suhteellisen vähän tutkittu ja että se vaatisi jäsennellympää empiiristä tukimusta. Yksittäisiä tutkimustuloksia hyvien oppimismahdollisuuksien ja hyvän osaamisen positiivisista hyvinvointivaikutuksista voidaan löytää, mutta nämä tulokset antavat myös viitteitä siitä, että yhteydet ovat todennäköisesti monimutkaisempia, kuin mitä julkisesta keskustelusta voidaan päätellä. Edellä esille nostettu ajatus välittävien tekijöiden roolista voisi olla yksi näkökulma tässä tarkastelussa. Tämän tutkimus pyrkii osaltaan motivoimaan esille nostettujen tärkeiden yhteyksien jatkotutkimusta erityisesti suhteessa koko ajan uudelleen määrittyvään työhyvinvointikäsitteeseen.

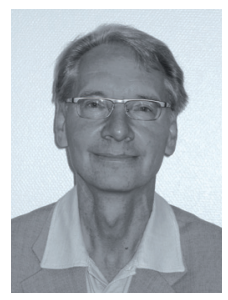

Pertti Laine

FT, tutkija

Elinikäisen oppimisen ja

koulutuksen tutkimuskeskus

(CELE),

Turun yliopisto

\section{LÄHTEET}

Acker, G. M. \& Lawrence, D. (2009). Social Work and Managed Care. Measuring Competence, Burnout, and Role Stress of Workers Providing Mental Health Services in a Managed Care Era. Journal of Social Work 9(3), 269-283.

Akerboom, S. \& Maes, S. (2006). Beyond demand and control: The contribution of organizational risk factors in assessing the psychological well-being of health care employees. Work \& Stress 20(1), 21-36.

Akkermans, J., Schaufeli, W.B., Brenninkmeijer, V. \& Blonk, R.B.W. (2013). The role of career competencies in the Job Demands-Resources model. Journal of Vocational Behavior 83, 356-366.

Alasoini, T. (2006). Työnteon mielekkyyden muutos Suomessa vuosina 1992-2005. Työolobarometrin aineistoihin perustuva analyysi. Tykes raportteja 45 . Helsinki: Työministeriö.

Antonovsky, A. (1993). The Structure and Properties of Sense of Coherence Scale. Social Science and Medicine 36(6), 725-733.

Antonovsky, A. (1987). Uraveling the Mystery of Health. San Fransisco: Jossey Bass.

Barlet, K.R. (2001). The Relationship Between Training and Organizational Commitment: A Study in the Health Care Field. Human Resource Development Quarterly 12(4), 335-352.

Berriman, J. (2007). Can coaching combat stress at work? Occupational Health 59(1), 27-29.

Bessick, J. \& Naicker, V. (2013). Barriers to tacit knowledge retention: An understanding of the perceptions of the knowledge management of people inside and outside the organization. South African Journal of Information Management.15(2)., 1-8.

Bowling, N.A., Eschleman, K.J., Wang, O., Kirkendall, C. \& Alarcon, G. (2010). A meta-analysis of the predictors and consequences of organizationbased self-esteem. Journal of Occupational and Organizational Psychology 83, 601-626. 
Busseri, M. A., Sadava, S. W., \& Decourville, N. (2007). A hybrid model for research on subjective wellbeing: Examining common- and componentspecific sources of variance in life satisfaction, positive affect, and negative affect. Social Indicators Research, 83, 413-445

Cha, J., Kim, Y. \& Kim, T. (2009). Person-career fit and employee outcomes among research and development professionals. Human Relations Volume 62(12), 1857-1886.

Chang, K. \& Lu, L. (2007). Characteristics of organizational culture, stressors and wellbeing The case of Taiwanese organizations. Journal of Managerial Psychology 22(6), 549-568.

Cheetham G. \& Chivers G. (2005). Professions, Competence and Informal Learning. Edward Elgar Publishing Ltd, UK.

Chen, T., Chang, P. \& Yeh, C. (2003). The study of career needs, career development programmes and job satisfaction levels of R\&D personnel: the case of Taiwan. International Journal of Human Resource Management 14(6), 1001-1026.

Chen, T., Chang, P. \& Yeh, C. (2004). An investigation of career development programs, job satisfaction, professional development and productivity: the case of Taiwan. Human Resource Development International 7(4), 441-463.

Colligan, T.W. \& Higgins, E.M. (2008). Workplace Stress: Etiology and Consequences. Journal of Workplace Behavioral Health, 21(2), 89-97.

De Grip, A., Sieben, I. \& Stevens, F. (2009) Are More Competent Workers More Satisfied? Labour 23(4), 589-607.

Diener, E., Suh, E.M., Lucas, R.E., \& Smith, H.E. (1999). Subjective wellbeing: Three decades of progress. Psychological Bulletin, 125, 276-302.

Engström, M., Skytt, B. \& Nilsson, A. (2011). Working life and stress symptoms among caregivers in elderly care with formal and no formal competence. Journal of Nursing Management 19, 732-741.
Feldt, T., Kinnunen, U. \& Mäkikangas, A. (2005). Affektiivisen hyvinvoinnin rakenne ja pysyvyys kolmen vuoden seuruututkimuksessa. Psykologia, 5-6, 541-551.

Fink, A. (2005). Conducting Research Literature Reviews: From the Internet to the Paper. Thousand Oaks: Sage Publications.

Gazioglu, S. \& Tansel, A. (2006). Job satisfaction in Britain: individual and job related factors. Applied Economics 38, 1163-1171.

Ghosh, R. \& Reio Jr, T.G. (2013). Career benefits associated with mentoring for mentors: A metaanalysis. Journal of Vocational Behavior 83, 106-116.

Graves, L.M. \& Luciano, M.M. (2013). Self-determination at work: Understanding the role of leader-member exchange. Motiv Emot 37, 518-536.

Hakanen, J. (2005). Työuupumuksesta työn imuun: työhyvinvointitutkimuksen ytimessä ja reunaalueilla. Työ ja ihminen tutkimusraportti 27. Helsinki: Työterveyslaitos.

Hamlin, B. (2010). What is HRD? A definitional review and synthesis of the HRD domain. Journal of European Industrial Training 35(3), 199-220.

Harbison, F.H. and Myers, C.A. (1964). Education, Manpower and Economic Growth: Strategies of Human Resource Development, McGraw-Hill, New York, NY.

Hosie, P., Jayashree, P., Tchantchane, A. \& Lee, B.S. (2013). The effect of autonomy, training opportunities, age and salaries on job satisfaction in the South East Asian retail petroleum industry. The International Journal of Human Resource Management 24(21), 3980-4007.

Howell, R.T., Chenot, D., Hill, G. \& Howell, C.J. (2011). Momentary Happiness: The Role of Psychological Need Satisfaction. Journal of Happiness Studies 12, $1-15$.

Hultell, D. \& Gustavsson, J.P. (2011). Factors affecting burnout and work engagement in teachers when entering employment. Work 40, 85-98. 
Ilmarinen, J. (2004). Jatkavatko ja jaksavatko suomalaiset työelämässä nykyistä pidempään? Tyó ja ihminen 18, 207-208.

Jarvis, P. (1988). Adult and continuing education. Theory and practice. London: Routledge.

Johnston, C.S., Luciano, E.C., Maggiori, C., Ruch, W. \& Rossier, J. (2013). Validation of the German version of the Career Adapt-Abilities Scale and its relation to orientations to happiness and work stress. Journal of Vocational Behavior 83, 295-304.

Järvensivu, A. \& Koski, P. (2009). Hyvä, parempi, innovaatio? Tutkimus organisatorisista innovaatioista työelämän laadusta ja työn mielekkyydestä. Tampereen yliopisto, Yhteiskuntatutkimuksen instituutti. Työelämän tutkimuskeskus. Työraportteja 84/2009.

Kalimo, R. \& Toppinen, S. (1997). Työuupumus Suomen työikäisellä väestöllä. Helsinki: työterveyslaitos.

Kallio, T.J. (2006). Laadullinen review-tutkimus metodina ja yhteiskunnallinen lähestymistapa. Hallinnon tutkimus 25(2), 18-28.

Karasek, R. A. (1979). Job Demands, Job Decision Latitude and Mental Strain: Implications for Job Redesign. Administrative Science Quarterly 24(2), 285-308.

Karasek, R. \& Theorell, T. (1990). Healthy Work, Stress, Productivity, and the Reconstruction of Working Life. Basic Books.

Kauppinen, T., Hanhela, R., Heikkilä, P., Kasvio, A., Lehtinen, S., Lindström, K., Toikkanen, J. \& Tossavainen, A. (toim.) (2007). Työ ja terveys Suomessa 2006. Helsinki: Työterveyslaitos.

Kehle, T. J. \& Bray, M. A. (2004). Rich theory: the promotion of happiness. Psychology in the Schools 41(1).

Ketola, H. U. (2010). Tulokkaasta tuottavaksi asiantuntijaksi. Perehdyttäminen kehittämisen välineenä eräissä suomalaisissa tietoalan yrityksissä. Akateeminen väitöskirja, Jyväskylä studies in business and economics 92. Jyväskylän yliopisto.

Kim, S. (2009). IT Employee Job Satisfaction in the Public Sector. International Journal of Public Administration 32, 1070-1097.

Kinnunen, U., Feldt, T. \& Mauno S. (toim.) (2005). Työ leipälajina: työhyvinvoinnin psykologiset perusteet. Jyväskylä: PS-Kustannus.
Ko, W. (2012). The relationships among professional competence, job satisfaction and career development confidence for chefs in Taiwan. International Journal of Hospitality Management 31. 1004-1011.

Korkalainen, A. \& Kokko, K. (2008). Psykologinen näkökulma aikuisiän hyvinvointiin ja siihen kytkeytyviin tekijöihin. Psykologia, 4, 261-273.

Laine, P. (2013). Työhyvinvoinnin kehittäminen. Hyvän kehittämisen reunaehtoja tutkimassa. Akateeminen väitöskirja, Turun yliopiston julkaisuja C 372, kasvatustieteiden tiedekunta Turku: Turun yliopisto.

Laine, P. (2014). Työhyvinvoinnin kehittäminen - mission impossible? Teoksessa I. Ranta \& E. Tilander (toim.) Hoitotyön vuosikirja 2014. Työhyvinvoinnin keinot. Suomen sairaanhoitajaliitto ry. Porvoo: Bookwell.

Lee, M. (1997). The developmental approach: a critical reconsideration. Teoksessa J. Burgoyne \& M. Reynolds (toim.), Management Learning. London: Sage, ss. 199-214.

Lee, M. (2001). A refusal to to define HRD. Human Resources Management International 4(3), 327-341.

Liang, S-C. \& Hsieh, A-T. (2005). Individual's Perception of Career Development and Job Burnout Among Flight Attendants in Taiwan. The International Journal of Aviation Psychology 15(2), 119-134.

Lyly-Yrjänäinen, M. (2014) Työolobarometri. Syksy 2013. Työ- ja elinkeinoministeriö, Työllisyysja yrittäjäosasto. [Online] http://www.tem.fi/ files/38687/TEMrap_5_2014_07022014.pdf . Luettu 15.2.2014.

Manka, ML. \& Siekkinen, P. (2008). Työhyvinvoinnin kehittämisen kivinen tie - kokemuksia EteläPirkanmaalla toteutetusta kehittämishankkeesta. Työelämän tutkimus 2, 198-203.

Martin, B. (2011). On being a happy academic. Australian Universities' Review 53(1), 50-56.

Maslach, C. \& Leiter, M. P. (1997). The Truth about Burnout: How Organizations Cause Personal Stress and What to Do about It. San Francisco, CA: JosseyBass.

Maslach, C. \& Leiter, M. P. (2008). Early Predictors of Job Burnout and Engagement. Journal of Applied Psychology 93(3), 498-512. 
McLagan, P.A. (Ed.) (1983). Models for excellence: The conclusions and recommendations of the ASTD Training and Development Competency Study. Washington DC: American Society for Training and Development.

Murad, M.S., O 'brien, M.L., Farnworth, L. \& Chien, C. (2013). Occupational competence and its relationship to emotional health in injured workers in return to work programs: A Malaysian study. Scandinavian Journal Occupational Therapy 20(2), 101-110.

Mäkitalo, J. (2005). Mitä on työhön liittyvä hyvinvointi. Teoksessa E. Paso, J. Mäkitalo \& J. Palonen (toim.) Viimeinen tykykirja? Merikosken kuntoutus- ja tutkimuskeskus ja Eläkevakuutusyhtiö Tapiola. Kolmas painos. Art-Print.

Nancarrow, S. (2005). The impact of intermediate care services on job satisfaction, skills and career development opportunities. Journal of Clinical Nursing 16, 1222-1229.

Naumanen, P. (2002) Koulutuksella kilpailukykyä. Koulutussosiologian tutkimuskeskuksen raportti 57. Turku: Turun yliopisto.

Nupponen, A. (2003). Käsiteanalyysi asiantuntijan työvälineenä. Teoksessa M. Koskela \& N. Pilke (toim.), Kieli ja asiantuntijuus. AFinLa-vuosikirja, 13-24. Jyväskylä: Suomen soveltavan kielitieteen yhdistys.

Paloniemi, S. (2004). Ikä, kokemus ja osaaminen työelämässä. Työntekijöiden käsityksiä iän ja kokemuksen merkityksestä ammatillisessa osaamisessa ja sen kehittämisessä. Akateeminen väitöskirja. Jyväskylä studies in education psychology and social research 253. Jyväskylän yliopisto.

Pan, A., Chung, L., Chen, T., Hsiung, P. \& Rao, D. (2011). Occupational Competence, Environmental Support and Quality of Life for People with Depression: A Path Analysis. American Journal of Psychiatric Rehabilitation Volume 14(1).

Panari, C., Guglielmi, D., Simbula, S. \& Depolo, M. (2010). Validation of the German version of the Career Adapt-Abilities Scale and its relation to orientations to happiness and work stress. Journal of Vocational Behavior 83, 295-304.
Paulsson, K., Ivergård, T. \& Hunt, B. (2005). Learning at work: competence development or competencestress. Applied Ergonomics 36, 135-144.

Poppius, E. (2007). The Sense of Coherence and Health. The Effects of the Sense of Coherence on Risk of Coronary Heart Disease, Cancer, Injuries and All-cause Mortality. Akateeminen väitöskirja, Tampereen yliopisto. Tampereen yliopistopaino Juvenes Print.

Proost, K., van Ruysseveldt, J. \& van Dijke, M. (2011). Coping with unmet expectations: Learning opportunities as a buffer against emotional exhaustion and turnover intentions. European Journal of Work and Organizational Psychology 21(1), 7-27.

Puusa, A. (2008). Käsiteanalyysi tutkimusmenetelmänä. Premissi 4, 36-43.

Raivola, R., Heikkinen, A., Kauppi, A., Nuotio, P., Oulasvirta, L., Rinne, R., Kamppi, P. \& Silvennoinen, H. (2006). Aikuisten opiskelumahdollisuudet ja järjestäjäverkko toisen asteen ammatillisessa koulutuksessa. Koulutuksen arviointineuvoston julkaisuja 15. Jyväskylä: Jyväskylän yliopistopaino.

Rau, R. (2006). Learning opportunities at work as predictor for recovery and health. European Journal of Work and Organizational Psychology 15(2), 158-180.

Rowden, R.W. \& Conine Jr, C.T. (2005). The impact of workplace learning on job satisfaction in small US commercial banks. Journal of Workplace Learning 17(4), 215-230.

Ryan, R.M., Huta, V. \& Deci, E.L. (2008). Living well: a self-determination theory perspective on eudaimonia. Journal of Happiness Studies 9, 139-170.

Samman, E. (2007). Psychological and Subjective Wellbeing: A Proposal for Internationally Comparable Indicators. Oxford Development Studies 35(4).

Sanchez, R., Heene, A. \& Thomas, H. (1996). Dynamics of Competence-Based Competition. Theory and practice in the new strategic management. Pergamon, Exeter.

Schaufeli, W.B., Daamen, J. \& van Mierlo, H. (1994). Burnout among Dutch Teachers: An MBI-Validity Study. Educational and Psychological Measurement 54(3), 803-812. 
Schaufeli W.B., Maslach, C. \& Marek, T. (1993). Professional Burnout. London: Taylor \& Francis.

Sethi, V., King, R.C. \& Quick, J.C. (2004). What causes stress in information system professionals? Communications of the Acm, 47(3), 99-102.

Sheldon, K.M., Abad, N., Ferguson, Y., Gunz, A., Houser-Marko, L., Nichols, C.P. \& Lyubomirsky, S. (2010). Persistent pursuit of need-satisfying goals leads to increased happiness: A 6-month experimental longitudinal study. Motiv Emot 34. 39-48.

Silvennoinen, H. \& Laine, P. (2014). Organisaatioiden henkilöstökoulutus - tarve ja oppimismahdollisuudet. Julkaisematon artikkelikäsikirjoitus. Turun yliopisto, kasvatustieteiden laitos.

Silvennoinen, H. \& Nori, H. (2012) Ikääntyvien koulutus monimuotoistuvassa työelämässä. Aikuiskasvatus 32 (3), 177-189.

Smith, E.A. (2005). Communities of competence: new resources in the workplace. Journal of Workplace Learning 17(1/2), 7-23.

SVT, Suomen virallinen tilasto: Aikuiskoulutustutkimus. Aikuiskoulutukseen Osallistuminen 2012. Helsinki: Tilastokeskus [online]. http://www.tilastokeskus. fi/til/aku/2012/01/aku_2012_01_2013-06-13_tie_001_ fi.html. Luettu 22.2.2014.

Tsai, H., Compeau, D. \& Haggerty, N. (2007). Of races to run and battles to be won: technical skill updating, stress, and coping of it professionals. Human Resource Management 46(3), 395-409.

TyövirePro (2013). Koulutusvapaan ABC. [online] http:// www.tyovirepro.com/tag/3-paivan-koulutusvapaa/. Luettu 11.2.2014.

Utriaianen, K. (2009). Arvostava vastavuoroisuus ikääntyvien sairaanhoitajien työhyvinvoinnin ytimenä hoitotyössä. Akateeminen väitöskirja. Oulun yliopisto, D Medica 1014.
Van Emerik, H. (2004). For better and for worse. Adverse working conditions and the beneficial effects of mentoring. Career Development International 9(4), 358-373.

Van Ruysseveldt, J., Verboon, P. \& Smulders, P. (2011). Job resources and emotional exhaustion: The mediating role of learning opportunities. Work \& Stress 25(3), 205-223.

Viitala, R., Mäkelä, L. \& Hölso, S. (2010). Lähijohtajuuden, esimies-alaissuhteiden ja työhyvinvoinnin välinen yhteys. Teoksessa TimoPekka Uotila (toim.) Ikkunoita osaamisen johtamisen systeemiseen kokonaisuuteen. Vaasan yliopiston julkaisuja, tutkimuksia 293, liiketaloustiede 106. Vaasa.

Viitala, R. \& Mäkipelkola, J. (2005). Työntekijä vuokrattuna. Vuokratyövoiman käytön vaikutuksia työyhteisössä. Työpoliittinen tutkimus 283. Työministeriö.

WiensTuers, B. \& Hill, E. (2002). Do They Bother? Employer Training of Temporary Workers. Review of Social Economy 60(4), 543-566.

Weng, R., Huang, C., Tsai, W., Chang, L., Lin, S. \& Lee, M. (2010). Exploring the impact of mentoring functions on job satisfaction and organizational commitment of new staff nurses. BMC Health Services Research 10(240), 1-9. 